\title{
Nasal allergen provocation test in nasal polyposis with and without allergy
}

\author{
Lien Calus", Lien Devuyst, Natalie De Ruyck, Thibaut Van Zele, Claus Bachert, Philippe Gevaert \\ From 9th Symposium of Experimental Rhinology and Immunology of the Nose (SERIN 2013) \\ Leuven, Belgium. 21-23 March 2013
}

\section{Background}

CRSwNP is characterised by eosinophilic inflammation and local IgE production. The amount of local tissue IgE in CRSwNP is independent of the atopic status and serum IgE of the patient. Moreover patients with CRSwNP and pollen allergy do not show prominent symptoms during season.

\section{Methods}

Four groups of patients $(n=48)$ underwent nasal allergen provocation test for grass pollen. We included 12 patients with allergic rhinitis based on grass allergy, 12 patients with CRSwNP without grass allergy, 12 patients with CRSwNP with grass allergy, and 12 control patients. The diagnosis of grass allergy was based on skin prick test and RAST. The test was positive based on change in nasal airflow measured by active anterior rhinomanometry and symptoms. In annex, VAS scores were performed before and after NAPT.

\section{Results}

The nasal allergen provocation test was positive in $19 \%$ of the patients with CRSwNP without allergy and in 54\% of the patients with CRSwNP with allergy. In contrast 100\% of the patients with allergic rhinitis developed a positive provocation test, whereas in the control group $8 \%$ of the patients developed a positive provocation test. CRSwNP without allergy did not show a significant increase in VAS scores of complaints. In contrast, allergic rhinitis patients and CRSwNP patients with grass allergy developed a significant increase in nasal obstruction and nasal drip. However, in allergic CRSwNP patient the symptoms after provocation were significantly lower compared to AR patients.

University Hospital Ghent, Upper Airway Research Laboratory, Ghent, Belgium

C) Biomed Central

\section{Conclusion}

This suggests that local IgE present in these patients are functional after allergen provocation with grass pollen. However there is a reduced reactivity after grass pollen stimulation in CRSwNP compared to allergic rhinitis. This reduced reactivity is most likely due to the polyclonality of local IgE or IgG4 blocking activity in CRSwNP.

Published: 16 July 2013

doi:10.1186/2045-7022-3-S2-014

Cite this article as: Calus et al:: Nasal allergen provocation test in nasal polyposis with and without allergy. Clinical and Translational Allergy 2013 3(Suppl 2):014.
Submit your next manuscript to BioMed Central and take full advantage of:

- Convenient online submission

- Thorough peer review

- No space constraints or color figure charges

- Immediate publication on acceptance

- Inclusion in PubMed, CAS, Scopus and Google Scholar

- Research which is freely available for redistribution

Submit your manuscript at www.biomedcentral.com/submit
C Biomed Central 